\title{
Faculty of Education
}

Faculty Publications

Indigenous Bilingual and Revitalization-Immersion Education in Canada and the USA

Onowa McIvor and Teresa L. McCarty

First Online: 04 January 2017

With permission from Springer International Publishing AG Switzerland.

Originally published at:

https://doi.org/10.1007/978-3-319-02258-1 34

Citation for this chapter:

McIvor, O. \& McCarty, T.L. (2017). Indigenous Bilingual and RevitalizationImmersion Education in Canada and the USA. In García O., Lin A., May S. (eds) Bilingual and Multilingual Education. Encyclopedia of Language and Education ( $3^{\text {rd }}$ ed.). Springer, Switzerland. https://doi.org/10.1007/978-3-319-02258-1 34 


\title{
Indigenous Bilingual and Revitalization- Immersion Education in Canada and the USA
}

\author{
Onowa Mclvor and Teresa L. McCarty
}

\section{Contents}

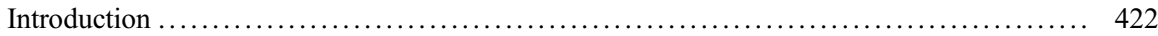

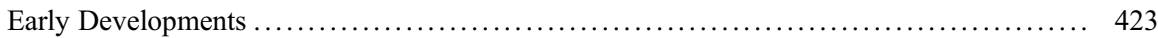

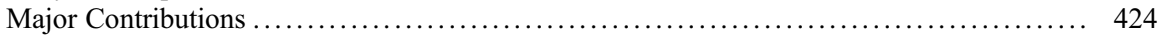

Indigenous Bilingual/Revitalization-Immersion Schooling in Canada .............. 425

Indigenous Bilingual/Revitalization-Immersion Schooling in the USA .............. 427

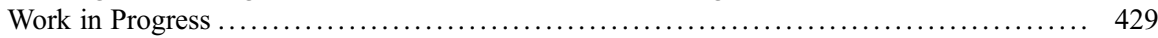

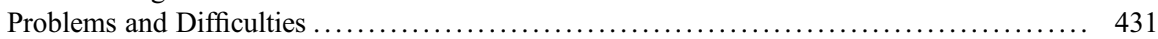

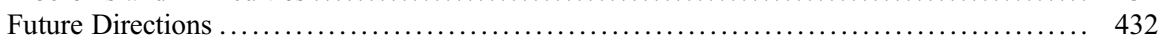

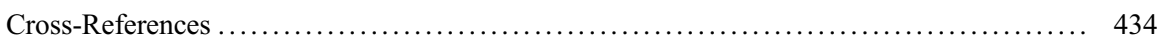

Related Articles in the Encyclopedia of Language and Education ..................... 434

References ............................................................ 435

\begin{abstract}
The sociolinguistic landscape in Native North America is defined by the combined realities of language loss and reclamation. In these contexts there is an overwhelming trend toward revitalization-immersion education undertaken in and out of school. The US Census data report 169 Native American languages spoken by 370,000 Native people; the Canadian Census data enumerate 240,815 Aboriginal people who report Aboriginal language conversational proficiency. An encouraging statistic in Canada has more Aboriginal people reporting Aboriginal language conversational proficiency than those reporting an Aboriginal
\end{abstract}

O. McIvor $(\bowtie)$

University of Victoria, Victoria, BC, Canada

e-mail: omcivor@uvic.ca

T.L. McCarty

Graduate School of Education and Information Studies, University of California Los Angeles, Los Angeles, CA, USA

e-mail: teresa.mccarty@ucla.edu; teresa.mccarty@asu.edu 
mother tongue, indicating that increasing numbers of Aboriginal language speakers in Canada are second language learners. Pairing linguistic diversity with increasing urbanization and diaspora realities creates additional challenges for Indigenous revitalization-immersion education, as does the diversity of school systems that Native students attend. Public schools - by far the most common school type - tend to have few Native teachers and minimal or no Native language and culture content. Given this sociolinguistic, demographic, and educational profile, this chapter provides an overview of historical and contemporary Indigenous language policies and practices across regions and within the two nation-states. Key cases are highlighted. Despite the challenges, Indigenous peoples in Canada and the USA are finding creative ways to bring their languages into new domains and new generations through Indigenous bilingual and revitalization-immersion education.

\section{Keywords}

Indigenous education - Aboriginal languages - Native American languages • Language revitalization $\bullet$ Immersion education

\section{Introduction}

The sociolinguistic landscape in Native North America is defined by the dual realities of language loss and reclamation. In these dynamic settings, the overwhelming trend is toward Indigenous language immersion or revitalization-immersion (cf. García 2009, pp. 247-251), "methods used to teach a language by using only that language" in everyday contexts (McIvor 2006, p. 5).

Those contexts are characterized by tremendous cultural and linguistic diversity coupled with relatively small numbers of people. Recent US Census data report 5.2 million American Indian and Alaska Native people (1.7\% of the population) and 1.2 million Native Hawaiian and other Pacific Islanders ( $0.4 \%$ of the population). The US Census also reports 169 Native American languages spoken by 370,000 people (Siebens and Julian 2011). Recent Canadian Census data enumerate 1.4 million First Nations, Métis, and Inuit people (4.3\% of the population), of whom 240,815 (17.2\% of the population) reported being able to converse in an Aboriginal language (Statistics Canada 2011a, b). In Canada, more Aboriginal people report conversational proficiency in an Aboriginal language than those reporting an Aboriginal mother tongue, indicating that more than $20 \%$ of Aboriginal language speakers are second language learners (Statistics Canada 2011a).

Pairing this linguistic diversity with increasing urbanization and diaspora realities creates additional challenges for immersion education for Indigenous peoples. This is further complicated by the various school systems Native students attend: federally run schools, federally funded but tribally controlled schools, parochial and other private schools, and public schools - by far the most common type serving Native students. Tribally operated schools in Canada, and parochial and public schools in 
both countries, are largely English medium. The exceptions are some public charter schools in the USA, which, by emphasizing Indigenous language and culture instruction, play a growing role in Native peoples' efforts to regain control over their children's schooling. Given this intra- and international diversity, this chapter provides an overview of historical and contemporary policies and practices across regions and within each nation-state, while highlighting key cases.

\section{Early Developments}

Multilingualism in Native North America long predates the European invasion and was common as a trade tool and for intertribal communication. For example, Philips (2011) documents dozens of Indigenous languages used along the Pacific Northwest Coast and inland territories during the eighteenth and nineteenth centuries, including many from outside the region such as Cree, Iroquois, Hawaiian, and Plains Sign languages.

Autochthonous literacies also flourished, including non-graphocentric systems such as winter counts (pictographic calendars), and alphabetic and syllabic writing systems. One such writing system is Cree syllabics, created in the early to mid-1800s and most often credited to Reverend James Evans (Macdonald 2011). Studies have shown that early use of syllabics was prolific among Cree communities, such that by the late eighteenth century, most Cree adults were literate in this writing system (Rogers 2005). Syllabic writing systems also constituted the foundation for early Cherokee and Choctaw bilingual schools in the southeastern USA, and an alphabetic writing system flourished under the Indigenous Hawaiian monarchy. In the latter cases, bilingual schooling in the Indigenous languages produced literacy rates that far exceeded those of the surrounding non-Native population. During the $1800 \mathrm{~s}$, for instance, the Hawaiian literacy rate "reached $90 \%$, 'the highest in the nineteenthcentury world"' (Grenoble and Whaley 2006, p. 95).

With the encroachment of settler societies, Indigenous education practices came under assault. As former British colonies, Canada and the USA have followed parallel trajectories in their policies toward Indigenous peoples and languages. The US 1819 Civilization Fund Act supported missionary schooling, with the goal of exterminating Native American languages and lifeways to clear the path for the seizure of Native lands. In Canada, the Indian Act of 1876 began a deliberate course of removal, genocide, and linguicide. In both national settings, by the late nineteenth and early twentieth centuries, punitive, segregated schooling in English- or Frenchmedium residential schools became a primary tool for exerting federal linguistic and territorial control.

Amidst the Civil Rights, American Indian, and progressive education movements of the late twentieth century, these policies and practices began to change. In the USA, the 1972 Indian Education Act funded Native language and culture programs, and the 1975 Indian Self-Determination and Education Assistance Act provided for Native American control over Native-serving schools. In Canada, Indigenous 
resistance peaked in a 1972 policy brief published by the National Indian Brotherhood (NIB), Indian Control of Indian Education, widely recognized as a "clear...call for an education system based on Aboriginal values and priorities" (Fettes 1998, p. 122).

By the early 1970s, 74 federally funded American Indian and Alaska Native bilingual education programs operated in the USA (Spolsky 1974). One precedentsetting example was the K-12 Navajo bilingual-biliteracy program at Rock Point, Arizona. At the time, nearly all Rock Point students entered school speaking Navajo as a primary language. On the theory that learning to read in the child's first language would result in enhanced literacy learning, Rock Point offered initial literacy in Navajo. In longitudinal assessments, Rock Point students consistently outperformed their peers in English-medium programs, and achievement gains were cumulative. Equally important, Rock Point students "had considerably more self-confidence and pride" (Holm and Holm 1995, p. 148). With the passage of the Indian Education Act and the Indian Self-Determination Act, programs using similar approaches were implemented in Native American community-controlled schools throughout the USA. In Canada, MacKenzie (1985) reports the first Indigenous-medium schools in eastern Cree territories. Indigenous-medium schooling experienced a resurgence following the Indian Control of Indian Education policy brief (NIB 1972), which brought syllabic-based Cree-medium education to a formal school setting for the first time.

Though significant, conventional bilingual education programs using Native American languages have not been sufficient to counter the myriad forces of language displacement and loss. As Hermes, Bang, and Marin (2012) explain, "While there are communities in which English has not claimed ownership, in many of our communities, children and families have no choice" but to use English in their everyday language practices (p. 398). This situation has given rise to a widespread language reclamation and revitalization movement, represented in the USA by the 1990/1992 Native American Languages Act and the 2006 Esther Martinez Native American Languages Preservation Act and in Canada by the Task Force on Aboriginal Languages and Cultures (2005), the 2007 Nunavut Official Languages Act, and the Inuit Language Protection Act. This movement is also reflected in the creation and implementation of Indigenous revitalization-immersion programs, to which we now turn.

\section{Major Contributions}

Increasingly Native North American communities favor immersion schooling solely because most Indigenous children no longer enter school proficient in their ancestral language. Bear Nicholas asserts, "As long as school for aboriginal children is conducted primarily in English and French, the colonial project of linguicide and cultural destruction will continue" (2013, p. 1). This section details examples of the longest-operating and most successful Indigenous bilingual and revitalizationimmersion schooling across Canada and the USA. 


\section{Indigenous Bilingual/Revitalization-Immersion Schooling in Canada}

Two contrasting Indigenous language education scenarios exist in Canada. Less common are programs that serve Indigenous children who are fully proficient in their ancestral language, providing instruction in their ancestral language and a colonial language (English or French). These programs are fairly exclusive to the far northern regions of Canada. Communities that subscribe to this schooling method generally share three traits: (1) they are small and geographically isolated; (2) one main Indigenous language exists in the area, or a decision has been made to support one language; and (3) the Indigenous language is the primary language of the community, with $90 \%$ or more of the residents being both Indigenous and proficient in the Indigenous language (Aylward 2010; McGregor 2012; Usborne et al. 2009). Unamen Shipu, Québec, is one community that fits this profile. Guévremont and Kohen (2012) report $99 \%$ of the Innu residents speak Innu, "from children through to elders" (p. 96). This community has chosen transitional bilingual education, starting with a 50/50 split of the day spent in Innu and French, the colonial language of choice in the region. In the students' second school year, French is the language of instruction with Innu as a subject for 45 minutes, two to three times per week (Guèvremont and Kohen 2012).

Similarly, the Inuit people of Nunavik, Québec, have implemented transitional bilingual education whereby children receive full immersion from kindergarten to grade 3 and then transition to English or French in grade 4. According to Usborne et al. (2009), while this community would prefer full immersion to continue beyond grade 3 , this aim has been constrained by practical barriers such as lack of curricula for higher grades and insufficient numbers of Inuit-speaking teachers.

More common in Canada are revitalization-immersion schools with the intent of producing bi-/multilingual outcomes for children who arrive proficient in one or both colonial languages but lack proficiency in their ancestral tongue. Four Indigenous groups in Canada are featured who offer this more prominent type of schooling from the Mohawk and Mi'kmaq of the east to Cree communities in Saskatchewan and Alberta and to British Columbia's interior Secwepemc Nation. Although other programs exist, these are the longest-running and best-known flagship immersion schools. However, none is well documented. At least one region - the Yukon Territory - is reported as having "no immersion programmes available in schools for any Yukon First Nations languages" (Ferguson 2010, p. 157).

The first reported Indigenous language immersion school in Canada is the Mohawk of Kahnawake, which began in 1970 (Jacobs 1998). Revitalization of Kanien'keha (the Mohawk language) was accelerated by a Native teacher preparation program at the University of Québec, in which preservice teachers created a practical writing system and curriculum designed to teach "children a way of thinking, not simply a translating skill” (Mithun and Chafe 1987, pp. 27-28). In 2015, the Kahnawake Education Center (KEC) reported a kindergarten through grade 6 immersion school, Karonhianonhnha Tsi Ionterihwaiensthakwa, and the Kahnawake Survival School for students in grades 7-11, which includes the teaching of Mohawk language, history, and culture (www.kec.qcc.com/schools). 
The Mohawk people are also well known for their adult Indigenous immersion programs, which, in tandem with Mohawk immersion preschools, are producing a new generation of adult and child speakers (Maracle et al. 2011).

The Mi'kmaq of the eastern Canadian coast are also known for the success of their K-12 Mi'kmaq language immersion programs. One such school is the Eskasoni Elementary and Middle School in Nova Scotia, which offers preschool to grade 2 full immersion before transitioning to the English-medium program (www. ekasonischool.ca/profile). Usborne et al. (2011) studied another Mi'kmaq school, Kina'matnewey, in which students are "taught each of their core subjects...in Mi'kmaq throughout the school year" (p. 205). This research focused on the Mi'kmaq and English language outcomes for students in an immersion program versus those in a Mi'kmaq second language program (defined as core subjects taught in English with Mi'kmaq as a second language for a minimum of 1 hour per day). The study also examined students' preparedness for postsecondary education in the colonial language (English). The research revealed that "students in the immersion program not only had stronger Mi'kmaq language skills compared to students in the second language program, but students within both programs ultimately had the same level of English" (Usborne et al. 2011, p. 200). As Battiste (2013) notes, "with results like these, one wonders why English-language programming for students who still have their Indigenous language used in the community would be used at all as the only language of instruction" (p. 93).

Cree is the largest language group in Canada. There are at least five distinct dialects that span as far eastward as Québec and reach the foothills of the Rocky Mountains in British Columbia to the west. Two Cree immersion schools have garnered scholarly attention: the Atikameg Sovereign School at Whitefish Lake First Nation in northern Alberta and the Onion Lake Cree Nation Kihew Waciston School in Saskatchewan. Bell et al. (2004) report that the Atikameg School offers a pre-K to grade 2 program, with a high level of Cree proficiency within the community. Onion Lake Cree Nation serves 65 students in full-immersion classes with the intent of developing a full-immersion curriculum. In 2015, Onion Lake Cree Nation reported serving 200 students in a full-immersion school (www.onionlake.ca/educa tion/kihew-waciston).

A fourth example of long-standing, successful Indigenous language immersion schooling in Canada is the Chief Atahm School near Chase, British Columbia, a region in which Secwepemc is spoken. Secwepemc revitalization began approximately 20 years ago with the launch of a language nest preschool founded by a few community mothers and elders (Michel 2012). This evolved into a kindergarten immersion program that extended through grade 8 . The school continues to operate successfully, with a portion of the community children attending. Most of the school staff are adult second language learners who have gained teaching degrees and high levels of proficiency sufficient to develop curriculum and teach all subjects in the Secwepemc language. The staff offers annual summer retreats for language teachers and other communities interested in starting immersion programs. This is the only known full-immersion school in British Columbia - a province that is home to more than half of all Indigenous languages in Canada (First People's Cultural Council 
[FPCC] 2014). Chief Atahm provides a strong example of the success that is possible in immersion schooling, even within a small community with a relatively small number of speakers and students.

\section{Indigenous Bilingual/Revitalization-Immersion Schooling in the USA}

Like Canada, there are very few Indigenous language maintenance bilingual education programs in the USA, and most are also concentrated in the Far North. Wyman and colleagues (2010) report on Yup'ik language maintenance in the Lower Kuskokwim School District (LKSD) in southwestern Alaska. In 1995, nearly all the villages served by LKSD were Yup'ik speaking, but by 2007, “educators were witnessing early signs of language shift" (Wyman et al. 2010, p. 30). These researchers found that the schools showing the highest achievement gains were those that "used Yup'ik as a consistent language of instruction in grades K-3 for 10 or more years" $(2010$, p. 41). In contrast, elementary schools that split their programming into separate Yup'ik and English strands witnessed the greatest evidence of language shift and lower academic gains among students.

Indigenous revitalization-immersion in the USA began in Hawai'i in 1983, when a small group of parents and language activists established the 'Aha Pūnana Leo (Hawaiian language nest) nonprofit organization. At the time, the number of children speaking Hawaiian had dwindled to fewer than 50 statewide (Wilson and Kamanā 2011). A grassroots Hawaiian "renaissance" had established Hawaiian as co-official with English in 1978. With support from Māori language educators in Aotearoa/New Zealand and Mohawk educators in Canada, the Pūnana Leo preschools enabled children to interact with fluent speakers entirely in Hawaiian, with the goal of cultivating new child speakers in much the same way as occurred in the home in earlier generations (Wilson and Kamanā 2011). As their children prepared to enter kindergarten, Pūnana Leo parents successfully lobbied for Hawaiianmedium elementary school tracks, and Hawaiian-medium schooling spread horizontally to other communities and vertically by grade. Today, Hawaiian-medium education serves 2,000 students statewide in a coordinated set of schools, beginning with the preschools and moving through full Hawaiian-medium elementary and secondary education.

One such school is the Nāwahīokalani‘ōpu'u (Nāwahī) Laboratory School in Hilo, a full-immersion, early childhood through high school program affiliated with the University of Hawai'i, Hilo, and 'Aha Pūnana Leo. The school teaches all subjects through Hawaiian, offering a college preparatory curriculum that explicitly prioritizes Hawaiian over English (Wilson and Kamanā 2011). Although Hawaiian language revitalization has been the priority, Nāwahī has yielded impressive English language results, with students surpassing their non-immersion peers on English standardized tests and outperforming the state average on high school graduation, college attendance, and academic honors (Wilson and Kamanā 2011). On a larger scale, the Hawaiian language revitalization movement is widely recognized as one of the most effective in the world, with more than 15,000 Hawaiians reporting that they 
use or understand Hawaiian. In addition to pre-K-12 schools, Hawaiian is widely taught in Hawaiian universities and has extended into nonschool domains such as Hawaiian-speaking sports.

In the southwestern USA, the Navajo Nation has been a primary site for Native language immersion programs (almost half of all self-reported speakers of Native American languages in the USA are Navajo). One of the most well-established programs is Tséhootsooí Diné Bi'ólta' (TDB), The Navajo School at the Meadow Between the Rocks, located in Fort Defiance, Arizona. In 1986, the Fort Defiance Elementary School launched a voluntary Navajo immersion program. At the time, most Fort Defiance students entered school speaking English as a primary language, and immersion represented "the only...program with some chance of success" at revitalizing the language among this group of children (Arviso and Holm 2001, p. 205). Program data showed that as children learned Navajo as a second language, their test performance in English also improved; immersion students performed better than non-immersion students on English writing assessments and were "way ahead" in mathematics (Holm and Holm 1995).

By 2003, the Fort Defiance immersion program had blossomed into the K-8 TDB School. Like Hawaiian immersion, a key program component is the involvement of parents and elders, who commit to spending time interacting with their children in Navajo after school. Longitudinal data show that TDB students consistently outperform their peers in English-only classrooms on local and state assessments of English reading, writing, and mathematics while also developing strong Navajo oral language and literacy skills (Johnson and Legatz 2006). Further, program cofounder Wayne Holm states, "What the children and their parents taught us was that Navajo immersion gave students Navajo pride in an urbanizing situation in which many students were not proud to be Navajo" (2006, p. 33).

As Native students increasingly attend off-reservation public schools, it is important to examine language revitalization efforts in urban school settings. A leading example is the K-5 Puente de Hózhọ́ (Bridge of Beauty) Trilingual Magnet School in Flagstaff, Arizona. The school's name mirrors its mission "to connect and celebrate the three predominant languages and cultures" of this urban community (Fillerup 2011, p. 150). To do this, the school offers a conventional Spanish-English dual immersion program and "one-way" Navajo revitalization-immersion for Englishdominant Navajo students. In a national study of promising practices in American Indian/Alaska Native education (McCarty 2012), Puente de Hózhọ́ (PdH) was identified as an exemplar for four reasons: (1) it explicitly rejects the remedial status historically accorded to bilingual and Indigenous education, emphasizing the value of multilingual, multicultural competence for all learners; (2) bilingual/immersion education is central, not auxiliary, to the curriculum; (3) like Nāwahī and TDB, PdH has exceptionally high levels of parent involvement - a practice widely associated with enhanced student achievement but rarely ascribed to Native families; and (4) $\mathrm{PdH}$ has consistently met state standards, with its students outperforming comparable peers in monolingual English programs in English language arts, 
mathematics, and English reading. PdH provides compelling evidence that making Indigenous students' languages and cultures "the centerpiece of instruction can pay astounding dividends academically, linguistically, and socially" (Fillerup 2011, p. 164).

\section{Work in Progress}

The research and programs profiled above demonstrate the proactive role that schools can play in language reclamation/revitalization when Native parents and community members control the curriculum and its implementation. As Holm (2006) notes, "Schools cannot save a language or culture," but they can "make it possible for students to find new and more meaningful ways of being [Indigenous] in the future" (p. 36). This work also testifies to the efficacy of full-immersion models, which produce graduates with high levels of Indigenous language proficiency and "academic and majority language outcomes equal to or surpassing those of peers in nonimmersion programs" (Wilson and Kamanā 2011, p. 46). Equally important, these programs have been shown to enhance cultural pride and intergenerational connections, and transform hegemonic expectations about Indigenous languages and cultures, from loss and extinction to resilience and self-empowerment.

These outcomes reflect and reinforce language planning underway at the national, state/provincial, and school/community/family levels. In the USA this includes provisions for Native American language revitalization-immersion programs in the 2015 Every Student Succeeds Act, the creation of a separate class of charter schools for Native language immersion in Alaska, Montana's recent support for K-12 Native language immersion in state public schools, and Arizona's Native American Language Certification Policy whereby tribes, in partnership with the state, certify Native language teachers. In Canada, parallel initiatives include the National First Nations Language Strategy adopted by the Assembly of First Nations (McDonald 2007), the FPCC's A Guide to Language Planning and Policy for [British Columbia] First Nations Communities (Franks and Gessner 2013), and the 2010 Northwest Territories Aboriginal Language Plan outlining state and Indigenous communities' shared responsibilities in Aboriginal language maintenance.

Implementing these language policies requires developing new education infrastructure support (Ball and McIvor 2013). Key needs are for qualified teachers who speak and understand the language and for high-quality teaching materials. One response has been the creation of Indigenous language teacher training programs aimed at cultivating second language learners while preparing them to develop curricula and teach in immersion settings. Bear Nicholas (2009) reports on the "first ever, native language immersion teacher-training programme in Canada," established in New Brunswick in 2001, which prepares Maliseet and Mi'kmaq teachers. These teachers have been "critical," Bear Nicholas states, to advocate for and implement immersion programs in maritime Indigenous communities (2009, p. 231). 
Another program is at the University of Victoria in British Columbia, Canada, where language learners concurrently study to be teachers in their own communities in order to remain close to mentor-speakers and to begin building the immersion programs their communities desire (www.uvic.ca/education/prospective/ indigenous/index.php). Yet another leading program is the Kahuawaiola Indigenous Teacher Education Program at the University of Hawai'i, Hilo, which involves teacher candidates in intensive immersion and a year of field-based training at Nāwah̄̄ School, followed by a year of student teaching in Hawaiian-medium schools (Wilson and Kawai'ae'a 2007). While not solely focused on immersion, other well-established teacher preparation and materials development programs that have been crucial to the Indigenous language reclamation movement include the long-lived American Indian Language Development Institute (AILDI) at the University of Arizona (www.aildi.arizona.edu), the Breath of Life Archival Institute for Indigenous Languages (http://www.endangeredlanguagefund.org/BOL_2013 home.php), and the Canadian Indigenous Languages and Literacy Development Institute (CILLDI) at the University of Alberta (www.cilldi.ualbera.ca).

Successful language revitalization also requires parents committed to enrolling their children in immersion programming and supporting language learning at home. As Hinton (2013) notes, many language revitalizers believe "the most important locus of . . revitalization is not in the schools, but rather the home,... the primary place where language acquisition occurs" (p. xiv). Hinton (2013) documents the language reacquisition strategies of parents and families involved in this movement, such as Daryl Baldwin (Miami) and jessie little doe baird (Wampanoag), whose ancestral languages had not been spoken for many decades, and Phil and Elaina Albers (Karuk), who, by apprenticing with a master language teacher/elder, made Karuk the language of their home. Family efforts have expanded to the community through classes, language documentation, collaborations with academic linguists, group meetings with elders, and language immersion summer camps. Like schoolbased efforts, this work challenges notions of language "extinction" and "death" (Leonard 2011), as languages that have not been spoken for as much as 150 years are being revived.

A fourth language reclamation/revitalization focus is the creative use of educational technologies. Hermes et al. (2012) report on design research with Ojibwe communities in which improvised movies based on elders' storytelling and naturally occurring speech during summer language camps provided new pedagogic resources for use inside and outside of school. "Repurposing" technology for language revitalization "opened spaces for the integration of Indigenous epistemologies and axiologies in learning materials" (2012, pp. 395-396). Adcock (2014) describes a host of computer-assisted technologies to record, preserve, and teach Native languages, including Cherokee claymation (stop motion animation using clay figures) animated films, Rosetta Stone software, web pages, newsletters, fonts, online radio programs, and bilingual talking dictionaries. Such projects mesh the goals of language documentation and community-based revitalization, emphasizing the need for - and benefits of - "teamwork across all stakeholders" (Penfield and Tucker 2011, p. 291). 


\section{Problems and Difficulties}

Despite tremendous efforts by Indigenous communities, educational organizations, and academics, a multitude of challenges to successful Indigenous bilingual/immersion schooling remain. The most obvious is the declining number of Indigenous language speakers. Most first language speakers are elders, and efforts to cultivate new speakers are not keeping pace with the rate of decline (for one regional example, see FPCC 2014). This is the crux of the often-discussed "race against time" which has made Indigenous language revitalization a paramount educational goal.

One response to this imperative has been language documentation, preserving spoken language using sophisticated recording equipment. For the most part, documentation has remained the purview of academic linguists. Tensions exist over whether documentation "fossilizes" Indigenous languages and disregards community-driven language education and revitalization goals. For communities with a handful of Native speakers, the dilemma may be whether to record those speakers' speech or immerse new learners in their presence through education efforts (e.g., the master-apprentice approach described in Hinton 2013). Many language activists argue that when there are so few speakers, their efforts should be invested in family- and community-based language planning, rather than in schools. Language documentation does not always produce accessible, usable materials for new learners or beginning speakers and rather uses valuable elder-speaker time and energy. To resolve these dilemmas, Penfield and Tucker (2011) call for greater collaboration between applied linguists and Indigenous community members and a retooling of skill sets, such that second language pedagogy is effectively linked to community-driven revitalization goals.

Creating new generations of speakers - both children and adults - also requires a corps of adult speakers who are prepared to teach in bilingual and immersion programs and schools. As illustrated by programs such as AILDI and CILLDI, postsecondary institutions are answering this call, yet this also requires expertise within those institutions in Indigenous second language learning and the ability to transfer that knowledge to effective programming. A new generation of Indigenous scholars and teacher educators with this combination of expertise is evident, but the need for more such scholar-practitioners is imperative.

For bilingual and revitalization-immersion education to be successful and sustainable also requires parents who understand the value of this type of schooling and are ideologically committed to it. Many scholars note the conundrum of parental fears of their children being "left behind" by their peers in mainstream schools. In Wyman et al.'s (2010) Yup'ik study, “parents expressed concern that Yup'ik programming might be holding their children back" (p. 38). As a consequence, these Yup'ik-speaking parents "started speaking English to their children before they even [started] school" (Wyman et al. 2010, p. 40).

Communities and school boards have much work to do to educate parents about the benefits of bilingual and revitalization-immersion schooling. Wyman et al. (2010) point to "direct evidence" that Yup'ik-serving schools demonstrating the highest English test gains were those that "used Yup'ik consistently as a primary 
language of instruction" (p. 40). Comparing English language outcomes for students enrolled in a Mi'kmaq immersion program and a Mi'kmaq-as-a-second-language program, Usborne et al. (2011) found similarly that the students in both programs demonstrated equivalent levels of English ability, while Mi'kmaq immersion students (not surprisingly) also developed stronger Mi'kmaq skills. These researchers concluded that, "Immersion programs can simultaneously revitalize a threatened language and prepare students for success in mainstream society" (p. 100).

Additional challenges include the great diversity and vast geographic span of Indigenous peoples and languages throughout the USA and Canada. The challenges of corpus planning - developing practical writing systems, teaching materials, etc. are exacerbated by geographic barriers between linguistically related communities. At the same time, the growing trend toward urbanization $(60 \%$ of Canadian Aboriginal people live in cities and more than $80 \%$ of Native people in the USA live outside tribal lands) raises questions for urban schools about which language(s) to privilege and how to provide Indigenous language support. Baloy (2011) posits that the local languages are given priority in revitalization efforts in keeping with Indigenous protocols of honoring one's local hosts. However, in most urban public school settings, Indigenous language support is lacking.

Finally, a profound challenge is the lack of supportive macro-level policies coupled with diffuse ideological forces favoring dominant languages and speakers. This both reflects and reproduces racialized linguistic discrimination and pedagogic practices that marginalize Indigenous languages. In the USA, numerous scholars describe the devastating impacts of high-stakes testing policies on the teaching of Indigenous languages and Indigenous educational and linguistic sovereignty. Multilevel policy changes are needed to better support communities in undertaking bilingual and immersion schooling. As Sarkar and Lavoie (2014) express, "These policies would...honour the linguistic traditions of the ancestors...[,] respect the...wishes of parents and families to preserve those traditions in healthy and multilingual communities [and] support children's potential to grow up as multiply-identified individuals" (p. 100). Such policies are supported by international conventions such as the United Nations 2007 Declaration on the Rights of Indigenous Peoples (www.un.org/esa/socdev/unpfii/documents/DRIPS_en.pdf) and the desires of Indigenous peoples themselves. As former Assembly of First Nations Chief Shawn A-in-chut Atleo (2013, p. 3) writes, "First Nations children must. . .be nurtured in an environment that affirms their dignity, rights, and identity, including their languages and cultures" (p. 3). He adds that this requires that education systems are supported and funded to achieve this overriding goal.

\section{Future Directions}

This chapter has documented the shift in focus from transitional and maintenance bilingual schooling to revitalization-immersion education, including school-, family-, and community-based initiatives. As Indigenous language reclamation has grown as both a grassroots movement and a scholarly discipline, greater attention is being paid 
to the reciprocal contributions of the field of second language acquisition. These linkages in scholarship and practice are evident in the emerging field of family language policy (FLP), defined as "explicit and overt planning [of] language use within the home among family members" (King et al. 2011, p. 907). Hinton (2013) documents families around the world who are creating sites of immersion in their kitchens and living rooms. In these cases, FLPs create sanctuaries for Indigenous language learning and use within the intimacy of family homes, long held by scholars such as Fishman (1991) to be the "bastion" of intergenerational language transmission. These family-based methods prepare children to enter revitalizationimmersion schooling while reinforcing language learning at home at the end of the school day. Other new approaches include "language houses" where small groups of learners live together for 3-6 months or more, immersing themselves in the language with the help of proficient speakers and other curriculum resources (Johnson 2014), and "language pods" in which learners gather to discuss preplanned topics, conversing only in the Indigenous language (Hinton 2013).

Increasing scholarly attention is also being paid to the crucial role of youth in language revitalization. New youth research is documenting the fallacy that Indigenous youth simply "abandon" their heritage language in favor of dominant languages. As Wyman et al. (2014) note, "many youth share adult allegiances to... maintaining Indigenous languages as part of Indigenous knowledge systems and ways of being" (p. 6). Yet youth are often positioned in challenging ways that cast their "incomplete" Indigenous language practices as problematic but charge them with the "daunting task" of "carrying their language into the future" (Wyman et al. 2010, p. 6). A related issue is how to convince youth that their language has worth and finding ways to demonstrate spheres for Indigenous language use outside the classroom. While many youth clearly feel the connection to their culture while learning their language (see, e.g., Wyman et al.'s [2014] discussion of youth "yearnings" for their heritage language), the influences of popular media in dominant languages can be overwhelming and detrimental to language revitalization. Youth need contemporary contexts for heritage language use; they need to be able to say "text me" and "later!" in the Indigenous language in order to reconcile their identities within the various domains in which they live. This requires corpus planning (e.g., relexification) at the school and community levels.

Finally, even as there is growing recognition of the potential of school-, family-, and community-based language reclamation efforts to reverse language loss, researchers are beginning to document the academic benefits of such efforts, including achievement in dominant language domains. Much more needs to be known about "the factors that contribute specifically to the educational effectiveness" of Indigenous-medium programs (Hill and May 2011, p. 162).

Following a fairly dark period of demise in the health of Indigenous languages, there is a growing focus and renewed vitality reflected in the creation of new speakers through a variety of methods. One reality is the growing presence of Indigenous languages in hegemonically "unexpected places" (Webster and Peterson 2011), including urban centers (Baloy 2011) and popular media created by Indigenous community members. The shift from endangerment to revitalization, and the 
creation of new speakers, has been described as a "new sociolinguistic order" (O'Rourke et al. 2015). Revitalization-immersion schooling has been fundamental in constructing this new order, as have extracurricular family- and community-based efforts. These language planning efforts challenge conventional notions of speakerhood, fluency, and bounded geographic territories of language acquisition and use. Instead, there is growing recognition of the multisited, heteroglossic, and hybrid character of Indigenous language practices (Webster and Peterson 2011). Rather than hindrances to language revitalization, these complex sociolinguistic characteristics are resources to be cultivated. As Indigenous communities and their non-Indigenous allies work together toward this goal, we can expect to see continued innovations in bilingual and revitalization-immersion schooling and an evergrowing presence of new Indigenous language speakers.

\section{Cross-References}

Language Rights and Bilingual Education

\section{Related Articles in the Encyclopedia of Language and Education}

T. Wiley: Policy Considerations for Promoting Heritage, Community, and Native American Languages. In Volume: Language Policy and Political Issues

L Hinton: Language Endangerment and Revitalization. In Volume: Language Policy and Political Issues

D. Patrick: Language Policy and Education in Canada. In Volume: Language Policy and Political Issues

K. Schultz and G. Hull: Literacies In and Out of School in the United States. In Volume: Literacies and Language Education

M. Farr: Literacies and Ethnolinguistic Diversity: Chicago. In Volume: Literacies and Language Education

M. Early, D. Dagenais and W. Carr: Second Language Education in Canada. In Volume: Second and Foreign Language Education

M. Met and A. Melnyk Brandt: Foreign language learning in K-12 classrooms in the United States. In Volume: Second and Foreign Language Education

G. Wigglesworth and B. Baker: Language Assessment in Indigenous Contexts in Australia and Canada. In Volume: Language Testing and Assessment

L.E. Poza, G. Valdés: Assessing English Language Proficiency in the United States. In Volume: Language Testing and Assessment

R. Brooks: Language Assessment in the US Government. In Volume: Language Testing and Assessment

L. Huss: Researching Language Loss and Revitalization. In Volume: Research Methods in Language and Education

A.-M. de Mejía: From Researching Translanguaging to Translanguaging Research. In Volume: Research Methods in Language and Education 
Andrew Lynch: Bilingualism and Second Language Acquisition. In Volume: Second and Foreign Language Education

Teresa McCarty: Language Education Planning and Policies by and for Indigenous Peoples. In Volume: Language Policy and Political Issues in Education

Leanne Hinton: Language Endangerment and Revitalization. In Volume: Language Policy and Political Issues in Education

Donna Patrick: Language Policy and Education in Canada. In Volume: Language Policy and Political Issues in Education

Wayne Wright: Language Policy and Education in the USA. In Volume: Language Policy and Political Issues in Education

L. Huss: Researching Language Loss and Revitalization. In Volume: Research Methods in Language and Education

\section{References}

Adcock, T. (2014). Technology integration in American Indian education: An overview. Journal of American Indian Education, 53(2), 104-121.

Arviso, M., \& Holm, W. (2001). Tséhootsooídí Ólta'gi Diné bizaad bihoo'aah: A Navajo immersion program at Fort Defiance, Arizona. In L. Hinton \& K. Hale (Eds.), The green book of language revitalization in practice (pp. 203-215). San Diego: Academic.

Atleo, S. (2013, November 25). Open letter to the Minister of Aboriginal Affairs and Northern Development in Canada. Retrieved from http://www.afn.ca/uploads/files/13-111-25_open_let ter_to_minister_valcourt_final.pdf

Aylward, M. L. (2010). The role of Inuit languages in Nunavut schooling: Nunavut teachers talk about bilingual education. Canadian Journal of Education, 33(2), 295-328.

Ball, J., \& McIvor, O. (2013). Canada's big chill: Indigenous languages in education. In C. Benson \& K. Kosonen (Eds.), Language issues in comparative education (pp. 19-38). Rotterdam: Sense Publishers.

Baloy, N. J. (2011). "We can't feel our language": Making places in the city for Aboriginal language revitalization. The American Indian Quarterly, 35(4), 515-548.

Battiste, M. A. (2013). Decolonizing education: Nourishing the learning spirit. Saskatoon: Purich.

Bear Nicholas, A. (2009). Reversing language shift through a Native language immersion teacher training program in Canada. In T. Skutnabb-Kangas, R. Phillipson, A. K. Mohanty, \& M. Panda (Eds.), Social justice through multilingual education (pp. 220-237). Bristol: Multilingual Matters.

Bear Nicholas, A. (2013, November 1). Language key to education for our indigenous children. Daily Gleaner, New Brunswick.

Bell, D., Anderson, K., Fortin, T., Ottoman, J., Rose, S., Simard, L., \& Spencer, K. (2004). Sharing our success: Ten case studies in Aboriginal schooling. Kelowna: Society for the Advancement of Excellence in Education.

Ferguson, J. (2010). Shäwthän dän, shäwthän kwänjè: Good people, good words: Creating a dän k’è speech community in an elementary school. Current Issues in Language Planning, 11(2), 152-172.

First People's Cultural Council (FPCC). (2014). Report on the status of B.C. First Nations languages. Brentwood Bay: First People's Cultural Council (FPCC).

Fettes, M. (1998). Life on the edge: Canada's Aboriginal languages under official bilingualism. In T. Ricento \& B. Burnaby (Eds.), Language and politics in the United States and Canada: Myth and realities (pp. 117-149). Mahwah: Lawrence Erlbaum. 
Fillerup, M. (2011). Building a "bridge of beauty": A preliminary report on promising practices in Native language and culture teaching at Puente de Hózhọ́ Trilingual Magnet School. In M. E. Romero-Little, S. J. Ortiz, T. L. McCarty, \& R. Chen (Eds.), Indigenous languages across the generations - Strengthening families and communities (pp. 145-164). Tempe: Arizona State University Center for Indian Education.

Fishman, J. A. (1991). Reversing language shift. Clevedon: Multilingual Matters.

Franks, S., \& Gessner, S. (2013). A guide to language policy and planning for B.C. First Nations communities. Brentwood Bay: First Peoples' Cultural Council.

García, O. (2009). Bilingual education in the 21st century: A global perspective. Malden: WileyBlackwell.

Grenoble, L., \& Whaley, L. (2006). Saving languages: An introduction to language revitalization. Cambridge, UK: Cambridge University Press.

Guèvremont, A., \& Kohen, D. E. (2012). Knowledge of an Aboriginal language and school outcomes for children and adults. International Journal of Bilingual Education and Bilingualism, 15(1), 1-27. doi:10.1080/13670050.2011.581268.

Hermes, M., Bang, M., \& Marin, A. (2012). Designing Indigenous language revitalization. Harvard Educational Review, 82, 381-402.

Hill, R., \& May, S. (2011). Exploring biliteracy in Māori-medium education: An ethnographic perspective. In T. L. McCarty (Ed.), Ethnography and language policy (pp. 161-183). New York: Routledge.

Hinton, L. (Ed.). (2013). Bringing our languages home: Language revitalization for families. Berkeley: Heyday Books.

Holm, W. (2006). The "goodness" of bilingual education for Native American children. In T. L. McCarty \& O. Zepeda (Eds.), One voice, many voices: Recreating Indigenous language communities (pp. 1-46). Tempe: Arizona State University Center for Indian Education.

Holm, A., \& Holm, W. (1995). Navajo language education: Retrospect and prospects. Bilingual Research Journal, 19, 141-167.

Jacobs, K. A. (1998). A chronology of Mohawk language instruction at Kahnawá:ke. In L. A. Grenoble \& L. J. Whaley (Eds.), Endangered languages: Language loss and community response (pp. 117-125). Cambridge, UK: Cambridge University Press.

Johnson, M. K. (2014). yaStmín cqwəlqwilt nixw, uł nixw, ul nixw, I need to speak more, and more, and more: Okanagan-Colville (Interior Salish) Indigenous second-language learners share our filmed narratives. Language Documentation and Conservation, 8, 136-167.

Johnson, F. T., \& Legatz, J. (2006). Tséhootsooí Diné Bi'ólta'. Journal of American Indian Education, 45(2), 26-33.

King, K. A., Fogle, L., \& Logan-Terry, A. (2011). Family language policy. Language and Linguistics Compass, 2(5), 907-922.

Leonard, W. Y. (2011). Challenging "extinction" through modern Miami language practices. American Indian Culture and Research Journal, 35(2), 135-160.

MacKenzie, M. (1985). Spelling reform among the James Bay Cree. In B. Burnaby (Ed.), Promoting Native writing systems in Canada (pp. 49-55). Toronto: OISE Press.

Maracle, I., Hill, K., Maracle, T., \& Brown, K. (2011). Rebuilding our language foundation through the next generation. In M. E. Romero-Little, S. Ortiz, T. L. McCarty, \& R. Chen (Eds.), Indigenous languages across the generations - Strengthening families and communities (pp. 83-94). Tempe: Arizona State University Center for Indian Education.

McCarty, T. L. (2012). Indigenous languages and cultures in Native American student achievement: Promising practices and cautionary findings. In B. Klug (Ed.), Standing together: American Indian education as culturally responsive pedagogy (pp. 97-119). Lanham: Rowman and Littlefield.

Macdonald, J. (2011). Anishiniiwi bimaadisiwin: Ojicree and (East) Cree experiences of Aboriginal literacies From Kasabonika, Mistissini, Waswanipi, and Waskaganish. Unpublished Master's thesis, Carleton University. 
McDonald, R.-A. J. (2007). Assembly of First Nations National First Nations language implementation plan. Ottawa: Assembly of First Nations.

McGregor, H. E. (2012). Nunavut's education act: Education, legislation, and change in the Arctic. Northern Review, 36, 27.

McIvor, O. (2006). Language nest programs in BC: Early childhood immersion programs in two First Nations communities. Brentwood Bay: First People's Cultural Council (FPCC).

Michel, K. A. (2012). Trickster's path to language transformation: stories of Secwepemc immersion from Chief Atahm School. Unpublished doctoral dissertation, Vancouver: University of British Columbia.

Mithun, M., \& Chafe, W. L. (1987). Recapturing the Mohawk language. In T. Shopen (Ed.), Languages and their status (pp. 1-34). New York: Winthrop.

National Indian Brotherhood (NIB). (1972). Indian control of Indian education/policy paper presented to the Minister of Indian Affairs and Northern Development. Ottawa: National Indian Brotherhood.

O’Rourke, B., Pujolar, J., \& Ramallo, F. (Guest Eds.). (2015). New speakers of minority languages: The challenging opportunity. Special issue, International Journal of the Sociology of Language.

Penfield, S. D., \& Tucker, B. V. (2011). From documenting to revitalizing an endangered language: Where do applied linguists fit? Language and Education, 25(4), 291-305.

Philips, L. (2011). Unexpected languages: Multilingualism and contact in eighteenth- and nineteenth-century North America. American Indian Culture and Research Journal, 35(2), $19-41$.

Rogers, H. (2005). Writing systems: A linguistic approach. Malden: Blackwell.

Sarkar, M., \& Lavoie, C. (2014). Language education and Canada's Indigenous peoples. In D. Gorter, V. Zenotz, \& J. Cenoz (Eds.), Minority languages and multilingual education (pp. 85-103). New York: Springer.

Siebens, J., \& Julian, T. (2011). Native North American languages spoken at home in the United States and Puerto Rico: 2006-2010. Washington, DC: U.S. Census Bureau.

Spolsky, B. (1974). American Indian education (Navajo Reading Study Progress Report No. 24). Albuquerque: University of New Mexico.

Statistics Canada. (2011a). Aboriginal peoples and language National Household Survey (NHS), 2011. Catalogue no. 99-011-X2011003. Retrieved from http://www12.statcan.gc.ca/nhs-enm/ 2011/as-sa/99-011-x/99-011-x2011003 1-eng.cfm

Statistics Canada. (2011b). Aboriginal people in Canada: First Nations peoples, Métis and Inuit. National Household Survey (NHS), 2011. Catalogue no. 99-011-X2011001. Retrieved from http://www12.statcan.gc.ca/nhs-enm/2011/as-sa/99-011-x/99-011-x2011001-eng.cfm

Task Force on Aboriginal Languages and Cultures. (2005). Towards a new beginning: A foundational report for a strategy to revitalize First Nation, Inuit and Métis languages and cultures. Ottawa: Aboriginal Languages Directorate/Aboriginal Affairs Branch/Department of Canadian Heritage.

Usborne, E., Caouette, J., Qumaaluk, Q., \& Taylor, D. M. (2009). Bilingual education in an Aboriginal context: Examining the transfer of language skills from Inuktitut to English or French. International Journal of Bilingual Education and Bilingualism, 12(6), 667-684. doi:10.1080/13670050802684388.

Usborne, E., Peck, J., Smith, D., \& Taylor, D. M. (2011). Learning through an Aboriginal language: The impact on students' English and Aboriginal language skills. Canadian Journal of Education, 34(4), 200.

Webster, A.K., \& Peterson, L.C. (Guest Eds.). (2011). Indians in unexpected places. Special issue, American Indian Culture and Research Journal, 35(2).

Wilson, W. H., \& Kamanā, K. (2011). Insights from Indigenous language immersion in Hawai' ${ }^{i}$. In D. J. Tedick, D. Christian, \& T. W. Fortune (Eds.), Immersion education: Practices, policies, possibilities (pp. 36-57). Bristol: Multilingual Matters. 
Wilson, W. H., \& Kawai'ae'a, K. (2007). I kumu; I lālā: "Let there be sources; let there by branches": Teacher education in the College of Hawaiian Language. Journal of American Indian Education, 46(3), 37-53.

Wyman, L., Marlow, P., Andrew, F. C., Miller, G. S., Nicholai, R. C., \& Reardon, N. Y. (2010). Focusing on long-term language goals in challenging times: A Yup'ik example. Journal of American Indian Education, $49(1$ \&2), 28-49.

Wyman, L., McCarty, T. L., \& Nicholas, S. E. (Eds.). (2014). Indigenous youth and multilingualism. New York: Routledge. 